\title{
Utvrđivanje programa politike suzbijanja zlouporabe novih psihoaktivnih tvari u Republici Hrvatskoj
}

\author{
Dr.sc. Dijana Jerković \\ Ured za suzbijanje zlouporabe droga Vlade Republike Hrvatske \\ Prof. dr. sc. Zdravko Petak \\ Sveučilište u Zagrebu, Fakultet političkih znanosti
}

Sažetak

Pojava novih psihoaktivnih tvari u Hrvatskoj počela je zaokupljati pažnju javnosti tek nedavno, iako je nacionalni Sustav ranog upozoravanja u slučaju pojave novih psihoaktivnih tvari ustrojen još 2007. godine. Prepoznavanju problema od strane javnosti pridonijela su izvješća o trovanjima i smrtnim slučajevima povezanim s konzumiranjem takvih tvari u državama članicama Europske unije, kao i njihova rastuća dostupnost u specijaliziranim trgovinama (tzv. smart shop) i na Internetu.

U ovom radu prikazat će se utvrđivanje programa politike novih psihoaktivnih tvari u Hrvatskoj, pri čemu će se primijeniti fazni model procesa stvaranja javnih politika, odnosno, model ciklusa javnih politika. Utvrđivanje programa javnih politika predstavlja početnu fazu procesa, stoga je svrha rada raspraviti aktivnosti, okolnosti i aktere koji su važni za postavljanje politike suzbijanja zlouporabe novih psihoaktivnih tvari na program političkog odlučivanja.

Ključne riječi: javne politike, utvrđivanje programa javnih politika, nove psihoaktivne tvari, sustav ranog upozoravanja u slučaju pojave novih psihoaktivnih tvari

Uvod

Posljednjih dvadesetak godina diljem Europe, a unatrag nekoliko godina i u Hrvatskoj, bilježi se rapidan porast novih psihoaktivnih tvari koje se ne nalaze na popisu UN-ove Jedinstvene konvencije o opojnim drogama iz 1961. godine niti UN-ove Konvencije o psihotropnim tvarima iz 1971. godine, a koje mogu predstavljati javno-zdravstvene rizike poput već zabranjenih tvari (Council of the European Union, 2005; Jerković, 2016). Ove tvari označavaju spojeve koji oponašaju učinke klasičnih droga, ali uključuju i nove načine zlouporabe već poznatih tvari (Council of the European Union, 2005; UNODC, 2015), što ukazuje na potrebu adekvatnog odgovora u vidu iniciranja sustavne politike kojom će se odgovoriti na problem.

Razumijevanje složenosti procesa kojim određeni društveni problem postaje javnom politikom zahtijeva shvaćanje konteksta unutar kojeg je započelo kreiranje javne politike (Young, Borland i Coghill, 2010). U skladu s tim, temeljna svrha ovoga rada je ukazati na procese koji su doveli do postavljanja politike sprječavanja zlouporabe psihoaktivnih tvari na dnevni red (odnosno, do utvrđivanja programa te politike). Navedeno će se istražiti kroz prikaz aktera, aktivnosti i okolnosti (konteksta) koje su obilježile proces postavljanja te politike na dnevni red političkog odlučivanja. Pri tome je potrebno napomenuti kako faza utvrđivanja dnevnog reda predstavlja analitičku kategoriju, a ne nešto što bi se moglo označiti kronološkim prikazom. Usmjeravanje istraživačke pozornosti na tu fazu oblikovanja politike sugerira da će događaji koji će uslijediti u 
daljnjim fazama, vezanim za formulaciju, način legitimiranja, provedbu i vrednovanje politike bitno biti određeni upravo tim prvim korakom. Način skretanja kolektivne pozornosti kreatora nacionalnih politika na pojedina društvena pitanja u samoj je srži određenja faze utvrđivanja dnevnog reda javnih politika (eng. policy agenda-setting). Navedeno utječe na daljnji razvoj, kao i na promjene pojedine politike (Green-Pedersen i Mortensen, 2013, 170). S obzirom na to da se temi novih psihoaktivnih tvari pristupa uglavnom s javno-zdravstvenog i zakonodavnog aspekta, u ovom se radu fenomenu novih psihoaktivnih tvari prvi put pristupa iz perspektive procesa stvaranja javnih politika. Navedenim pristupom želi se doprinijeti širem prepoznavanju ovog problema sa stanovišta različitih dionika, a s ciljem unaprjeđenja postojeće prakse u oblikovanju te politike. U svijetu su razmjerno malobrojna istraživanja u kojima se politika sprječavanja zloporabe droga specifično povezuje s fazom postavljanja dnevnog reda javnih politika, odnosno s utvrđivanjem programa te politike. Jedan od primjera odnosi se na pokušaje primjene modela postavljanja dnevnog reda razvijenog u radovima Rogera Cobba i suradnika na politike sprječavanja zloporabe droga u SAD-u tijekom 1970-ih i 1980-ih (Sharp, 1992).

\section{Uporaba novih psihoaktivnih tvari u Republici Hrvatskoj}

Problem novih psihoaktivnih tvari u Republici Hrvatskoj niz godina nije bio prepoznat kao problem javnih politika, budući da se tijekom 2000-tih kod nas bilježi tek sporadična identifikacija novih psihoaktivnih spojeva. Ipak, istraživanja uporabe sredstava ovisnosti u različitim ciljanim skupinama posljednjih godina ukazuju na prisutnost i konzumiranje ovih tvari. Primjerice, drugo Istraživanje zlouporabe droga u općoj populaciji Republike Hrvatske, koje je provedeno na reprezentativnom uzorku građana Republike Hrvatske u dobi između 15 i 64 godine ( $N=4$ 992), pokazalo je kako je životna prevalencija uzimanja bilo koje nove psihoaktivne tvari među osobama u dobi 15-64 godine 2,7\%, dok je među osobama u dobi 15-34 nešto viša i iznosi 5,4\%. (Glavak Tkalić, Miletić i Maričić, 2016). Istraživanje dostupnosti i uporabe ovih tvari na prigodnom uzorku mladih osoba (90\% sudionika je bilo u dobnoj skupini od 18 do 40 godina) koje je provedeno 2011. ( $N=1330$ ) i 2013. ( $N=1$ 035) na forumu „Forum.hr", pokazalo je kako su sudionici istraživanja u velikoj mjeri upoznati s novim trendovima u konzumiranju psihoaktivnih tvari te kako imaju saznanja o tome gdje ih nabavljati i kako ih koristiti (Kranželić i Jerković, 2012; Kranželić i Doležal, 2013). Na slične rezultate ukazuje i Flash Eurobarometar, istraživanje o mladima i drogama koje je provedeno u lipnju 2014. godine među 13128 građana Europske unije starosti između 15 i 24 godine. Istraživanje je pokazalo kako je u Europskoj uniji 8\% sudionika u dobi od 15 do 24 godine konzumiralo neku novu psihoaktivnu tvar, dok je isto učinilo 7\% sudionika u Republici Hrvatskoj (European Commission, 2014). Nove psihoaktivne tvari dostupne su i među studentima visokoškolskih institucija, na što upućuje Istraživanje kvalitete života studenata u Republici Hrvatskoj ( $N=1880$; Kovčo Vukadin, 2014). Nadalje, istraživanje provedeno na kvotnom uzorku (s obzirom na spol i područje studiranja) od 438 studenata (37,9\% mladića i 62,1\% djevojaka) prve i druge godine preddiplomskih studija kojima je 2014./2015. odobren smještaj u studenska naselja Sveučilišta u Zagrebu je pokazalo kako je 3\% sudionika barem jednom u životu konzumiralo sintetske kanabinoide, pri čemu nije utvrđena statistički značajna razlika po spolu (Jerković, 2015). Među srednjoškolcima, prevalencije konzumiranja novih psihoaktivnih tvari nešto su više. Naime, najnoviji rezultati ESPAD istraživanja koje je provedeno među šesnaestogodišnjacima u 35 europskih zemalja pokazuju kako se učenici u Hrvatskoj ( $\mathrm{N}=2$ 558) nalaze iznad europskog prosjeka u konzumiranju novih psihoaktivnih tvari: 
čak $7 \%$ sudionika navodi kako je barem jednom u životu probalo nove psihoaktivne tvari (Kraus i sur., 2016). Nadalje, istraživanje provedeno među korisnicima programa smanjenja šteta, kao jedne od rizičnih skupina, pokazalo je kako ove tvari u Hrvatskoj nisu popularne među intravenoznim konzumentima opijata koji su uključeni u programe smanjenja šteta (Doležal, 2012).

Čini se kako se nove psihoaktivne tvari u Hrvatskoj još uvijek konzumiraju rekreativno. Ipak, iako je riječ o relativno niskim prevalencijama uporabe, potencijalni javno-zdravstveni rizici povezani s njihovom konzumacijom nisu zanemarivi, osobito uzme li se u obzir nedovoljno poznavanje djelovanja ovih tvari.

\section{Utvrđivanje dnevnog reda i proces stvaranja javnih politika}

Najuobičajeniji pristup javnim politikama u središte istraživačke pozornosti stavlja proces njihovog stvaranja (Colebatch, 2004; Hill, 2010; Cairney, 2013). Riječ je o racionalističkom razumijevanju procesa stvaranja politika u kojem se oblikovanje, provedba i vrednovanje javnih politika prikazuju kao svojevrsni kružni ciklus rješavanja problema u nizu zasebnih sekvenci koje se razlikuju prema broju aktera i logici uzročnosti. Broj faza tako shvaćenog ciklusa razlikuje se od autora do autora. Utemeljitelj javnih politika kao zasebne akademske discipline, Harold Lasswell, vidi sedam takvih distinktivnih faza, od početne faze obavještavanja (eng. intelligence) do evaluacije, kao završne faze. Različite varijante slojevanja ciklusa razrađuje u domaćoj literaturi Grdešić (1995), a danas se u literaturi o javnim politikama ipak najčešće rabi tumačenje ciklusa stvaranja politika koje polazi od pet ili šest zasebnih faza: postavljanje dnevnog reda, formulacija, legitimiranje, implementacija i evaluacija, s time da se ponekad posljednja faza rastače u fazu vrednovanja i odluke o tome treba li politiku nastaviti ili ne (Hill, 2010; Hogwood i Gunn,1984; Howlett, Ramesh i Perl, 2009).

Javne politike se unutar takvog konceptualnog okvira shvaćaju kao kolektivni odabir politika za zajednicu, gdje se uspostavljanjem, razvojem i provedbom politike u pojedinom sektorskom području nastoji utjecati na rješavanje problema s kojima se zajednica suočava. Upotrebom analitičkih alata zasnovanih na omeđivanju procesa stvaranja i provedbe politika u zasebne faze nastoje se utvrditi pravilnosti koje postoje u pojedinim sekvencama stvaranja politika, načini prelaska iz jedne fazu u drugu ili pak broj aktera koji u svemu tome sudjeluje (Petak, 2007; Petak, 2008). U praksi nerijetko postoji raskorak s teorijskim modelom faznog ciklusa te je ovaj nerijetko bio podvrgnut snažnoj kritici. Kritičari su nastojali osporiti tvrdnju da se oblikovanje politika odvija temeljem jasno utvrđenih faza koje se na linearan način nadovezuju jedna na drugu. Neovisno o nizu kritika koje se mogu uputiti takvom shvaćanju procesa stvaranja javnih politika, on je široko prihvaćen u akademskim istraživanjima. Možda i ključni razlog tome leži u činjenici koju spominje britanski istraživač Peter John ističući da je fazna heuristika donijela neku vrstu reda u istraživanjima javnih politika, ali istodobno i odvojila javne politike kao akademsku disciplinu od legalističkog proučavanja institucija, kakvo dominira u pravnim znanostima (John, 1998).

Faza utvrđivanja dnevnog reda predstavlja možda i najkritičniju fazu ciklusa stvaranja politike, budući da događaji iz ove faze imaju odlučujući utjecaj na preostali dio ciklusa i njegove temeljne ishode. Ovu fazu karakterizira prepoznavanje određene pojave kao problema javnih politika koji zahtijeva daljnju pozornost vlade (Dearing i Rogers, 1996; Jones i Baumgartner, 2005; Baumgartner, Green-Pedersen i Jones, 2006; Princen, 2009). Dnevni red javnih politika i način njegovog utvrđivanja 
ne odnosi se pri tome samo na skup društvenih problema, već i na razumijevanje uzroka tih problema, na simbole vezane uz dnevni red te na rješenja društvenih problema. Drugim riječima, određeno društveno stanje treba biti percipirano kao nezadovoljavajuće, promjenjivo, društveno konstruirano kao kolektivni problem te prepoznato prioritetom kako bi institucije vlasti nešto učinile da ga riješe (Petek, 2012; Petek, 2014, 54-55). Na taj način društveni problem postaje problem javnih politika, odnosno dolazi na dnevni red političkog odlučivanja.

\section{Vrste i obilježja utvrđivanja dnevnog reda javnih politika}

U razdoblju rastućih promjena, globalizacije i individualizacije javne politike ne nastaju kao isključivi ishod odlučivanja na temelju vlasti, već kao posljedica procesa u kojem se problemi javnih politika prepoznaju od strane šire javnosti. U pravilu, teorije javnih politika usmjeravaju se na tri analitičke dimenzije: aktere, institucije i ideje, zbog čega istraživanje javnih politika predstavlja zahtjevan zadatak, pri čemu se u obzir uzimaju državni i društveni akteri uključeni u proces donošenja odluka (Hajer, 2003). Kada je posrijedi istraživanje djelovanja aktera i njihovog utjecaja na razvoj javnih politika bitno je istražiti djelovanje ne samo aktera koji donose autoritativne odluke (vlast), već i aktere koji u stvaranju pojedinih politika sudjeluju temeljem zainteresiranosti za te politike (dionici). Sukladno tome, aktere koji sudjeluju u oblikovanju javnih politika temeljem dimenzije vlasti možemo označiti kao vertikalne aktere, a one koji sudjeluju temeljem suradnje i pregovaranja o politici kao horizontalne aktere javnih politika (Colebatch, 2004).

Jedan od najznačajnijih istraživača u ovom području, američki politolog John Kingdon, $u$ svom klasičnom djelu Agendas, Alternatives and Public Policies (Kingdon, 1984) ističe da je promjene u dnevnim redovima javnih politika potrebno vezivati uz dva zasebna aspekta. Prvi se odnosi na pokazatelje uočenog problema, temeljem kojih se pokušava utvrditi veličina problema s kojim se zajednica suočava i stupanj nužnosti poduzimanja odgovarajućih mjera. Drugi aspekt koji može utjecati na promjene dnevnog reda odnosi se na različite vrste prijelomnih događaja kojima se usmjerava pozornost javnosti na neki društveni problem (eng. focusing events). Riječ je o svemu onome što doprinosi osnaživanju pozornosti vezane za neko važno pitanje s čijim rješavanjem se zajednica mora suočiti. Povećanje pozornosti, pri tome, stvara situaciju koja može dovesti do promjene politike u promatranom sektorskom području. Tom je aspektu postavljanja dnevnog reda u posljednjih nekoliko desetljeća posvećena razmjerno opsežna literatura (Birkland i DeYoung, 2013) i smatra se jednim od validnijih teorijskih pristupa u razmatranju utvrđivanja programa javnih politika. Istraživači javnih politika koji polaze od tog pristupa razlikuju područja javnih politika u kojima ne postoji značajnije prisustvo javnosti, od područja javnih politika u kojima je na djelu veliki upliv javnosti. Riječ je o razlikovanju koje je svojedobno postavio poznati teoretičar javnih politika Peter May, razlikujući "dvije vrste političkih okolina - politike bez i politike s javnošću” (May, 1990).

Nasuprot takvim istraživanjima utvrđivanja dnevnog reda javnih politika postupno je razvijan alternativni, post-pozitivistički pristup, koji je stavio naglasak na subjektivnu konstrukciju problema javnih politika i ulogu aktera i paradigmi. Riječ je o različitim interpretativnim pristupima koji su ukazali na niz važnih pitanja koja utječu na određivanje programa, odnosno, dnevnih redova javnih politika. Tu je prije svega riječ o radovima kojima se daje novi okvir problemu (eng. framing), što je posebno došlo do izražaja u radovima koje su svojom klasičnom studijom pokrenule poznate 
teoretičarke javnih politika Schneider i Ingram (1993). Osim toga, niz drugih istraživanja ukazao je na veliku važnost što ih u postavljanju politika na dnevni red političkog odlučivanja imaju vrste naracija, simbola, jezika koji rabe zagovarači tih politika. Naime, ideje aktera javnih politika imaju značajan utjecaj na donošenje odluka, stoga tradicija, uvjerenja i stavovi o svijetu i društvu utječu na način na koji pojedinci interpretiraju svoje interese (Flathman, 1966, prema Howlett, Ramesh i Perl, 2009). Osobitu važnost predstavljaju ideologije, budući da one predstavljaju temeljna uvjerenja i uzročna objašnjenja koja služe kao svojevrsni putokazi za aktivnosti, definiranje problema, utjecaj na stratešku interakciju aktera javnih politika i ograničavanje opsega ponuđenih odgovora na izazove pojedinih politika. Uzimajući u obzir navedeno, jedna od najpoznatijih teoretičarki javnih politika, Deborah Stone, navodi kako utvrđivanje dnevnog reda uključuje konstruiranje "narativa" o tome što je uzrokovalo predmetni problem vezan uz pojedinu politiku (Stone, 2012).

Nastojanja da se što bolje uspije sistematično kombinirati neke od ranije identificiranih središnjih varijabli u sveobuhvatniju i empirijski točniju teoriju o utvrđivanju dnevnog reda javnih politika, rezultirali su razvojem multivarijatnih modela. Ovi modeli pokušavaju obuhvatiti odnos između društvenih, institucionalnih, ideoloških, političkih i gospodarskih uvjeta u procesu utvrđivanja dnevnog reda i polaze od pretpostavke da na predmet dnevnog reda utječu socio-ekonomsko i fizičko okruženje, raspodjela moći u društvu, prevladavajuće ideje i ideologije, institucionalni okvir vlade te proces donošenja odluka (Mazmanian i Sabatier, 1980). Upravo pretpostavka uzročne raznolikosti u razumijevanju postavljanja problema javnih politika na dnevni red političkog odlučivanja predstavlja najznačajniju snagu modela.

Nastavno na navedeno, još je sedamdesetih godina 20. stoljeća, jedan od suutemeljitelja teorije racionalnog izbora, Anthony Downs (1972), predložio koncept ciklusa usmjeravanja na problem (eng. issue-attention cycle), prema kojemu se proces nastanka javne politike često fokusira na problem koji u određenom trenutku zaokuplja pozornost i potiče zahtjev javnosti za aktivnost vlade, čime se omogućuje uvođenje inovativnih javnih politika.

U svom klasičnom djelu o utvrđivanju dnevnog reda javnih politika, koje je predstavljalo neku vrstu prekretnice u razvoju taksonomija javno-političkih agendi, Cobb i Elder (1972, prema Howlett, Ramesh i Perl, 2009) utvrdili su razlikovanje sistemskog, institucionalnog i dnevnog reda na kojem se donose odluke. Pod prvi izraz podveli su sva pitanja koja akteri stvaranja javnih politika percipiraju kao probleme zajednice, pod drugi sva pitanja koja oni koji obnašaju vlast smatraju važnima i na kojima se aktivno angažiraju, a tek su trećim izrazom obuhvatili situacije donošenja odluka o stvarnom pokretanju javnih politika. Time su značajno doprinijeli razumijevanju faze utvrđivanja dnevnog reda, budući da su prvi puta u akademskoj literaturi pojašnjeni različiti tipovi dnevnog reda. Sistemski dnevni red (neformalni) sastoji se od tema koje su prepoznate od članova zajednice javnih politika i koje zahtijevaju reakciju vlade. Najčešće je riječ o društvenom dnevnom redu koji uključuje diskusiju o individualnim ili društvenim problemima, poput kriminaliteta ili zdravstvene zaštite. Međutim, samo manji dio tema koje se nalaze na sistemskom dnevnom redu dobije odgovarajuću pozornost vlade (Howlett, Ramesh i Perl, 2009). Naime, tek kada vlada prepozna određeni problem, smatra se da se pojava našla na institucionalnom (formalnom) dnevnom redu. Proces tijekom kojeg problem vezan uz neku politiku prolazi od neformalnog do institucionalnog utvrđivanja dnevnog reda sastoji se od četiriju međufaza (Cobb, Ross i Ross, 1976) - iniciranja diskusije, specificiranja mogućih rješenja problema, širenja podrške za njegovo prepoznavanje te, ukoliko 
je navedeno uspješno provedeno, uvođenja problema pojedine politike na dnevni red političkog odlučivanja. Kako bi se dobio uvid u širu sliku problema, potrebno je povezati navedene tipove dnevnog reda s kontekstom (Howlett, Ramesh i Perl, 2009).

Važnost konteksta prepoznao je još sredinom 1980-ih John Kingdon (1984) uvođenjem koncepta "prozora javnih politika" (eng. policy window). Pod navedenim konceptom podrazumijeva se konstruiranje i korištenje mogućnosti utvrđivanja dnevnog reda, uz uvažavanje interakcije triju tijekova o kojima ovisi postavljanje politika na dnevni red političkog odlučivanja - tijeka problema, tijeka javnih politika (eng. policy stream) i političkog tijeka (eng. political stream). Razvoj problema podrazumijeva percepciju pojave kao pitanja vezanog uz pojedinu politiku koje zahtijeva politički odgovor, pri čemu se osobito važnim prepoznaju stručnjaci koji istražuju problem i nude mogućnosti za njegovo rješavanje. U konačnici, na politički odgovor utječu nacionalno raspoloženje, administrativni ili zakonodavni zaokret i aktivnosti interesnih skupina. Navedene komponente mogu egzistirati neovisno jedna od druge sve do trenutka otvaranja "prozora javnih politika" u kojem dolazi do interakcije problema, rješenja i mogućnosti za djelovanje (Kingdon, 1984, 174-180).

Za razumijevanje dinamike koja vodi preklapanju spomenutih triju tijekova osobito su važna istraživanja koja su od početka 1990-tih poticali američki politolozi Frank Baumgartner i Bryan Jones (1991). U tom kontekstu, potrebno je spomenuti pojam podsustava javnih politika (eng. policy subsystems), kojim se u akademskoj literaturi o razvoju politika označavaju razmjerno stabilne skupine „aktera s dostatnom razinom znanja o nekom problemskom području, ili o raspoloživim resursima, što im omogućuje sudjelovanje u procesu oblikovanja alternativnih smjerova djelovanja da bi se razmotrilo pitanja koja su istaknuta u fazi postavljanja dnevnog reda" (Howlett, Ramesh i Perl, 2009, 12). U skladu s tim, postoje podsustavi koji imaju dominantno monopolističke, odnosno, natjecateljske značajke. Unutar prve vrste postoji ustaljeni obrazac rasprava o promatranoj politici, a akteri koji sudjeluju u raspravi o promatranoj politici ili o njezinim bitnim aspektima, te institucionalni obrasci unutar kojih se sve to odvija, su ustaljeni i bez mogućnosti bitnih promjena. S druge strane, natjecateljski sustavi uvode elemente rasprave i osporavanja, omogućavaju mijenjanje temeljnih okvira i diskursa promatrane politike, kao i promjenu politike. Spomenute podsustave moguće je povezati s temeljnim značajkama ideja o javnim politikama, odnosno s tim je li riječ o starim ili novim idejama. Spajanjem dviju vrsta podsustava javnih politika i dviju vrsta ideja o javnim politikama dobivaju se četiri temeljne vrste načina postavljanja dnevnog reda javnih politika (Howlett, Ramesh i Perl, 2009, 106-107): 1. status quo, koji je zasnovan na monopolističkom podsustavu i starim idejama; 2 . osporavajući, zasnovan na natjecateljskom tipu sustava i starim idejama; 3. redefinirajući, zasnovan na monopolističkom podsustavu i starim idejama i 4. inovativni, zasnovan na natjecateljskom podsustavu i novim idejama. Ključna varijabla koja se mijenja u spomenuta četiri modela je način na koji se prikazuje promatrani javno-politički problem, odnosno, njegova slika (eng. image) u raspravama unutar konkurentskih podsustava i/ili javnosti. Pri tome je važno razlikovanje politika s obzirom na razinu utjecaja javnosti, na što je prethodno već ukazano pozivanjem na istraživanja koja je poduzeo May (1990). Baumgartner i Jones (1991) također pokazuju da neki problemi s kojima se suočava zajednica zadobivaju dominantnu sliku kao tehnička pitanja, a u njihovom rješavanju važnu ulogu imaju eksperti koji dominiraju procesom stvaranja te politike. S druge strane, pitanja koja imaju širi društveni i politički značaj zahtijevaju participaciju šire javnosti i uključenost većeg broja zainteresiranih pojedinaca i skupina. Dakle, za razumijevanje 
prijepora o načinu prikaza konkretnog problema javnih politika ključno je nadmetanje „pojedinaca i skupina koje imaju moć unutar postojećih podsustava i onih koji nastoje utjecati na te podsustave rabeći sredstva vanjskog utjecaja" (Howlett, Ramesh i Perl, 2009, 106).

Polazeći od spomenutih postavki Baumgartner i Jones 1993. razvijaju svoju varijantu modela isprekidane ravnoteže (eng. punctuated equilibrium) koji je postao jednim od najutjecajnijih pristupa za razumijevanje dinamike postavljanja javnih politika na dnevni red političkog odlučivanja (Baumgartner i Jones, 2009). Riječ je o pristupu koji polazi od toga da proces stvaranja javnih politika prate razmjerno duga razdoblja ustaljenih i uravnoteženih obrazaca ponašanja i institucionalnih ustroja, praćenih iznenadnim i naglim promjenama. Na snage održavanja postojećeg stanja i održavanja ravnoteže dominantno utječu tzv. negativni feed-back procesi, poduprti različitim mehanizmima osporavanja različitih prijedloga politika da dođu na dnevni red političkog odlučivanja (eng. agenda denial). S druge strane, mogućnost prekidanja ustaljenih ravnoteža donose pozitivni feed-back procesi, koji uzrokuju nagle promjene promatrane politike. Nakon toga se ponovno uspostavlja stanje dugoročne stabilnosti, unutar kojeg su moguće samo inkrementalne promjene. U kasnijim radovima Baumgartner i Jones su priznali da postoji određena sličnost njihovog modela s modelom zagovaračkih koalicija, kojeg su u isto vrijeme razvili Paul Sabatier i Hank Jenkins-Smith (1993). No, navedeni modeli se i značajno razlikuju. Dok se model zagovaračkih koalicija zasniva prije svega na sustavima uvjerenja i vrednota, model isprekidane ravnoteže je zasnovan prije svega na alociranju, odnosno, preusmjeravanju pozornosti na određena pitanja javnih politika, što ih poduzimaju njihovi kreatori. Preusmjeravanje pozornosti događa se, prema njihovom sudu, na "iščašen i zbrkan", gotovo epizodni način, uzrokujući snažne iznenadne promjene (Jones i Baumgartner, 2012, 4).

Za razliku od prethodno navedenih pristupa, kojima se snažno ističe važnost naglih promjena u načinu stvaranja javnih politika, valja navesti i autore koji smatraju suprotno. Nizozemski teoretičar Marteen Hajer (2003) navodi kako je u promjenjivom kontekstu kreiranja javnih politika potrebno uzeti u obzir izazove povezane s raspršenim redoslijedom donošenja odluka, odnosom kreiranja javne politike i političkog odlučivanja, potrebom za preispitivanjem standardnog pogleda na sudjelovanje i demokratsko vođenje, promjenjivom ulogom klasične znanstvene ekspertize te opsežnim kontekstom u kojem se javna politika kreira. Pretpostavljeni politički kontekst analize politika sastoji se od minimalno tri elementa: političkog odlučivanja, znanja i intervencije (Hajer, 2003). Drugim riječima, Hajer smatra da stabilan politički poredak predstavlja preduvjet za kreiranje politike, znanje treba biti znanstveno utemeljeno iako se producira u svrhu političkog odlučivanja, a intervencija je u pravilu problemski orijentirana i ima za cilj mijenjanje postojećeg stanja.

\section{Utvrđivanje dnevnog reda politike suzbijanja zlouporabe novih psihoaktivnih tvari u Republici Hrvatskoj}

U nastavku rada, prilikom prikaza utvrđivanja programa / dnevnog reda politike suzbijanja zlouporabe novih psihoaktivnih tvari u Republici Hrvatskoj pokušat će se identificirati Hajerovi (2003) elementi: politički poredak, znanje i intervencije. U svrhu boljeg razumijevanja stanja u području ove politike primijenit će se i teorija mreže aktera (eng. „An Actor Network Theory”).

Utvrđivanje dnevnog reda politike suzbijanja zlouporabe novih psihoaktivnih tvari predstavlja višegodišnji proces u kojem su značajnu ulogu imali različiti akteri, u prvom redu akteri na europskoj 
razini. Naime, od početka 1990-tih, diljem Europske unije bilježi se pojava tzv. dizajnerskih droga, najčešće psihotropnih tvari povezanih s amfetaminom i MDMA-om. Njihova pojavnost potaknula je pitanja oko eventualnih zdravstvenih rizika i problema do kojih bi moglo doći ukoliko bi se navedene tvari nalazile pod zakonskom kontrolom u pojedinim, ali ne i u svim državama članicama. Kao odgovor na postojeću situaciju, zaključeno je kako bi se značajan napredak mogao postići razmjenom informacija te provedbom procjena rizika i mehanizama za njihovu eventualnu kontrolu diljem Europske unije (EMCDDA, 2007.). Navedeno je rezultiralo donošenjem Zajedničke akcije o razmjeni informacija, procjeni rizika i kontroli novih sintetskih droga (Council of the European Union, 1997.) koja je služila kao temelj za razvoj mehanizma ranog upozoravanja. Potrebno je napomenuti kako su novim sintetskim drogama smatrane tvari koje su imale ograničenu terapeutsku vrijednost, koje se u to vrijeme nisu nalazile na popisu UN Konvencije o psihotropnim tvarima iz 1971., a predstavljale su ozbiljan rizik za javno zdravstvo poput tvari na Listi I i Listi II Konvencije. Pri tome se pridjev "novi” nije odnosio samo na novonastale tvari, već i na novu zlouporabu ranije poznatih tvari (EMCDDA, 2007). Odlukom 2005/387/JHA Vijeća o razmjeni informacija, procjeni rizika i kontroli novih psihoaktivnih tvari (Council of the European Union, 2005), ovaj je mehanizam proširen na sve nove psihoaktivne tvari kojom je ustrojen EU Sustav ranog upozoravanja u slučaju pojave novih psihoaktivnih tvari. Na razini EU-a glavni čimbenici koji su suodgovorni za upravljanje sustavom su Europski centar za praćenje droga i ovisnosti o drogama (eng. European Monitoring Centre for Drugs and Drug Addiction - EMCDDA) i Europol, a neizostavne partnere predstavljaju i nacionalne kontaktne točke kao dijelovi Europske informacijske mreže za droge i ovisnosti o drogama (Reitox - franc. Réseau Européen d'Information sur les Drogues et les Toxicomanies) koja predstavlja ljudsku i informacijsku povezanost nacionalnih informacijskih sustava.

U vrijeme usvajanja Zajedničke akcije i Odluke Vijeća Republika Hrvatska nije bila članica Europske unije. Ipak, 2002. godine na nacionalnoj razini počele su institucionalne promjene koje su rezultirale osnivanjem Ureda za suzbijanje zlouporabe droga (Uredba o osnivanju Ureda za suzbijanje zlouporabe opojnih droga, NN 18/2002, 12/2005, 111/2006, 19/2010, 36/2012, 130/2012, a temeljem Zakona o suzbijanju zlouporabe droga, NN 107/2001, 87/2002, 163/2003, 141/2004, 40/2007, 149/2009, 84/2011). Već 2003. godine Ured je započeo neformalnu suradnju s EMCDDAom1, a 2006. godine je pri Uredu osnovan Odjel Nacionalne informacijske jedinice za droge i poslove međunarodne suradnje (NN 111/2006) - nacionalna kontaktna točka EMCDDA-a. U užem smislu riječi, temelje za razvoj politike suzbijanja zlouporabe novih psihoaktivnih tvari u Hrvatskoj postavile su Nacionalna strategija suzbijanja zlouporabe (opojnih) droga u Republici Hrvatskoj za razdoblje 2006.-2012. (NN 147/2005) i Nacionalna strategija suzbijanja zlouporabe droga u Republici Hrvatskoj za razdoblje 2012.-2017. (NN 122/2012) kao temeljni dokumenti politike suzbijanja zlouporabe droga. Spomenuti strateški dokumenti, a osobito posljednji, predvidjeli su stvaranje sustava brze razmjene podataka o proizvodnji, trgovanju, uporabi i rizicima novih psihoaktivnih tvari kako bi se mogli spriječiti njihovi negativni učinci. Uslijedilo je donošenje Protokola o Sustavu ranog upozoravanja, kojeg je Vlada Republike Hrvatske usvojila 2007. godine. U prosincu 2010. godine potpisan je Sporazum između Republike Hrvatske i Europske unije o sudjelovanju Republike Hrvatske u radu Europskog centra za praćenje droga i ovisnosti o drogama, kojeg je Hrvatski sabor potvrdio u ožujku 2013. usvajanjem Zakona o potvrđivanju Sporazuma između Republike Hrvatske i Europske unije o sudjelovanju Republike Hrvatske u radu Europskog centru za praćenje droga i

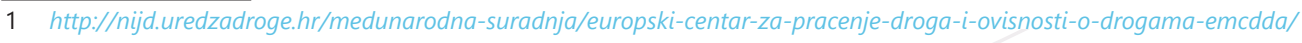


ovisnosti o drogama (NN 03/2013, Međunarodni ugovori). Time su, u skladu s Ustavom Republike Hrvatske (NN 56/1990, 135/1997, 113/2000, 28/2001, 76/2010, 05/2014), odredbe Sporazuma postale dio unutarnjeg pravnog poretka Republike Hrvatske. Opisani zakonodavni postupci i izvršni akteri u prikazanom tijeku razvoja politike suzbijanja zlouporabe novih droga predstavljaju političko odlučivanje, odnosno preduvjet za kreiranje javne politike, kojeg Hajer (2003) još naziva i političkim poretkom.

Upotreba znanja što ga o procesima političkog odlučivanja stvaraju znanosti koje se bave javno-političkim diskursima može biti raznolika i u osnovi se odnosi na različite razine kompleksnosti pokazatelja o javnim politikama (Kustec Lipicer, 2008). Rastuće znanje predstavlja drugu važnu komponentu u kreiranju javne politike (Hajer, 2003). Ova komponenta je osobito važna za razumijevanje funkcioniranja Sustava ranog upozoravanja u slučaju pojave novih psihoaktivnih tvari. S obzirom na to da u navedenom vremenu nije postojala realna ugroza od novih psihoaktivnih tvari u Hrvatskoj, šira društvena prepoznatljivost ovog problema javlja se tek nedavno s rastućom pojavom trovanja i smrtnih slučajeva povezanih s konzumacijom novih psihoaktivnih tvari u članicama Europske unije, sumnjivim trovanjima u Hrvatskoj te sve većim interesom medija za pojavu novih droga. Na europskoj razini, informacije o prvi puta identificiranim novim psihoaktivnim tvarima EU Sustava ranog upozoravanja pokazuju kako je, primjerice, tijekom 2008. godine identificirano 13 novih tvari (EMCDDA / Europol, 2012, 3), u 2012. ukupno 74 nova spoja (EMCDDA/Europol, 2013, 5), a u 2015. njih čak 98 (EMCDDA, 2016, 30). Zanimljivo je spomenuti kako EU Sustav ranog upozoravanja trenutno prati preko 560 novih psihoaktivnih spojeva (EMCDDA \& Eurojust, 2016).

U Hrvatskoj, glavni izvor informacija o novim psihoaktivnim tvarima predstavljaju podaci Centra za forenzička ispitivanja, istraživanja i vještačenja „Ivan Vučetić" temeljeni na zapljenama i identificiranju novih psihoaktivnih tvari. Uz to, postupno su problem prisutnosti ovih tvari prepoznale i nevladine organizacije koje provode programe smanjenja šteta, budući da su provoditelji ovih aktivnosti u neposrednom kontaktu s konzumentima droga pa imaju i saznanja o ovim pojavama. Nadalje, kako bi se dobio detaljniji uvid u uporabu novih psihoaktivnih tvari, proveden je i niz prethodno spomenutih istraživanja među različitim ciljanim skupinama, koja ukazuju na rekreativno konzumiranje ovih tvari.

Kako bi se omogućilo poduzimanje adekvatnih intervencija, koje Hajer (2003) spominje kao treći neizostavni element u kreiranju javne politike, ustrojen je nacionalni Sustav ranog upozoravanja. Prvu razinu Sustava čini neposredna suradnja EMCDDA-a i Odjela Nacionalne informacijske jedinice za droge i poslove međunarodne suradnje pri Uredu za suzbijanje zlouporabe droga, odnosno Europola i nacionalne jedinice u Hrvatskoj. Ured za suzbijanje zlouporabe droga, kao koordinator Sustava ranog upozoravanja u Hrvatskoj, odgovoran je za koordinaciju suradnje među nacionalnim partnerima, daljnji razvoj Sustava, planiranje i nadzor provedbe planiranih aktivnosti, prikupljanje i širenje informacija te izvješćivanje i izravnu komunikaciju s EMCDDA-om. Drugu razinu Sustava predstavlja Radna skupina koju čine predstavnici ključnih nacionalnih tijela i institucija, nevladinih organizacija i drugi priznati stručnjaci na tom području. Treća razina sačinjena je od organizacijskih jedinica unutar pojedinog podsustava, a zadužena je za prosljeđivanje informacija do krajnjih korisnika, prikupljanje saznanja o pojavnosti novih psihoaktivnih tvari na terenu i izvješćivanje o istom predstavnika u Radnoj skupini. Konačno, četvrta se razina smatra Širom mrežom Sustava i uključuje medije, konzumente droga, druge skupine u riziku i širu javnost (Protokol o Sustavu 
ranog upozoravanja u slučaju pojave novih psihoaktivnih tvari, 2007). Uz navedeno, mehanizam razmjene informacija omogućava i praćenje provedenih aktivnosti te predstavlja osnovu za sveobuhvatnu procjenu provedbe politike na temelju različitih izvora podataka (Protokol o Sustavu ranog upozoravanja u slučaju pojave novih psihoaktivnih tvari u Republici Hrvatskoj, 2007). Najjasnijih primjer intervencije odnosi se na zakonsku kontrolu novih tvari. U početku su zakonski kontrolirane pojedine nove psihoaktivne tvari koje su predstavljale javno-zdravstveni rizik na nacionalnoj i/ili europskoj razini. Međutim, stavljanje svake pojedine tvari na listu droga ne rješava problem pojave novih modificiranih inačica kontroliranih tvari (Huhges i Evans-Brown, 2015), stoga je u siječnju 2016. izrađen generički Popis droga, psihotropnih tvari i biljaka iz kojih se može dobiti droga te tvari koje se mogu uporabiti za izradu droga (NN 10/16) koji je stavio pod zakonsku kontrolu cijele skupine novih psihoaktivnih tvari.

lako su u postavljanju na javno-politički dnevni red zastupljeni preduvjeti političkog poretka, znanja i intervencije (Hajer, 2003), politika suzbijanja zlouporabe novih psihoaktivnih tvari u Hrvatskoj još uvijek nije prepoznata javno-političkim prioritetom. U boljem razumijevanju mogućih razloga za navedeno poslužit ćemo se teorijom mreže aktera, budući da se u okviru ove teorije osobit naglasak stavlja na kontekst u kojem se odvija promjena struktura i procesa određenog sustava (Young, Borland i Coghill, 2010). U kontekstu Sustava ranog upozoravanja, znanstvene dokaze tj. identificiranje novih psihoaktivnih tvari omogućio je Centar za forenzička ispitivanja, istraživanja i vještačenja „Ivan Vučetić". Nadalje, Ured za suzbijanje zlouporabe droga, kao koordinator Sustava, od početka je prepoznao važnost ovog problema kao pitanja javnih politika te je umrežavao relevantne aktere, organizirao edukacije za različite skupine profesionalaca, inicirao stavljanje novih psihoaktivnih tvari pod zakonsku kontrolu i osmišljavao aktivnosti suzbijanja legalne prodaje novih droga. Druga razina Sustava ranog upozoravanja predstavlja saveznike u iniciranju promjena, a temelji se na dvosmjernom prosljeđivanju informacija i umrežavanju šire mreže profesionalaca koji se nalaze u direktnom kontaktu s konzumentima (treća razina Sustava). Uz navedeno, suradnja sa znanstvenim institucijama, provedba istraživanja dostupnosti i prevalencija uporabe novih psihoaktivnih tvari te komunikacija s medijima omogućavaju dobivanje uvida u javno mnijenje o ovoj pojavi. Prema navedenoj teoriji (Young, Borland i Coghill, 2010), proces institucionalizacije javne politike odvija se kroz tri međusobno preklapajuće faze: autonomizaciju problema, odabir rješenja i približavanje prema rješenju. Autonomizacija je usko povezana s postavljanjem javne politike na dnevni red, budući da uključuje prikupljanje informacija o pojavi kroz istraživanja i pokušaje praćenja različitih dimenzija pojave, diskusiju zainteresiranih aktera, medijska izvješća o pojavi, izvještavanje političkih struktura o stanju problema te osviještenost šire zajednice o opasnostima koje nose nove psihoaktivne tvari. Odabir rješenja uključuje potencijalne izmjene zakonodavstva, generičku listu kontroliranih tvari, jačanje drugih mehanizama za implementaciju politike kroz mobiliziranje šire mreže aktera (primjerice, prikupljanjem informacija iz zdravstvenog sustava o trovanjima i smrtnim slučajevima povezanim s novim psihoaktivnim tvarima) te društvenu prihvaćenost aktivnosti praćenja i suzbijanja problematike novih psihoaktivnih tvari. Konačno, približavanje prema rješenju uključuje procjenu javnih troškova povezanih s ovom problematikom, povećanu razinu svijesti o negativnim zdravstvenim učincima novih droga te denormalizaciju zlouporabe tzv. "osvježivača prostora" i "soli za kupanje", krivo deklariranih proizvoda pod kojima se prodaje dio novih psihoaktivnih tvari. Faza utvrđivanja dnevnog reda javnih politika u najvećoj mjeri obuhvaća aktivnosti iz faze autonomizacije, dok se preostale faze teorije mreže aktera tek predstoje implementirati. 


\section{Zaključak}

Javnu politiku može se razmatrati kao logičan niz koraka koje poduzimaju kreatori javnih politika da bi, korištenjem različitih vrsta instrumenata, ostvarili određene društvene ciljeve (Petak, 2008). Ostvarivanje spomenutih ciljeva uvijek se odvija unutar određenog institucionalnog konteksta te je istovremeno poduprto utjecajem različitih ideja o tome kakve trebaju biti politike koje se primjenjuju u nekoj zajednici. Zbog lakšeg razumijevanja logike stvaranja i razvoja određene javne politike vrlo često se koristi pristup zasnovan na faznom modelu njihova razvoja. Takav je model primijenjen i u ovome radu, s time da je naglasak stavljen na prvu fazu ciklusa javnih politika - utvrđivanje programa politike, odnosno, postavljanje njezinog dnevnog reda. Ovu fazu karakterizira postavljanje pitanja koja pripadaju fazi inicijacije politike, odnosno odluke o tome hoće li se politika na nekom području provoditi ili se neće provoditi (Hague, Harrop i Breslin, 2001). Drugim riječima, predstavljanjem određenog problema kao važnog pitanja nastoji se uvjeriti mjerodavna tijela i širu zajednicu javnih politika u činjenicu da postoji stvaran problem koji zahtjeva djelovanje (Young i Quinn, 2007).

U kontekstu politike suzbijanja zlouporabe novih psihoaktivnih tvari u Republici Hrvatskoj potrebno je napomenuti da, iako su strateški elementi za predmetnu politiku postavljeni još prije desetak godina te, unatoč činjenici da je Sustav ranog upozoravanja u slučaju pojave novih psihoaktivnih tvari u Republici Hrvatskoj formalno uspostavljen 2007. godine, pojava novih psihoaktivnih tvari niz godina nije izazivala dovoljan interes relevantnih aktera. Prva istraživanja uporabe ovih tvari počela su se provoditi 2011., a tek su rastuća pojava trovanja i smrtnih slučajeva povezanih s konzumiranjem novih psihoaktivnih tvari u državama Europske unije (EMCDDA, 2014), anegdotalna izvješća o trovanjima ovim spojevima u Hrvatskoj, sve veći interes medija za ovaj fenomen te njihova dostupnost u specijaliziranim trgovinama (tzv. smart shop) i na Internetu rezultirali povećanim interesom za ovaj problem.

Sukladno podjeli Cobba i Eldera (1972; prema Howlett, Ramesh i Perl, 2009), tema novih psihoaktivnih tvari još se uvijek nalazi na sistemskom utvrđivanju dnevnog reda, koji se uglavnom sastoji od diskusije relevantnih stručnjaka različitih razina Sustava ranog upozoravanja. Riječ je o načinu oblikovanja politike u kojem se utvrđivanje programa te politike odvija poglavito djelovanjem stručnjaka kao horizontalnih aktera, odnosno, dionika javnih politika koji mogu surađivati na stvaranju politike, no ne mogu donositi autoritativne odluke o njoj. Promatrano modelski, hrvatski slučaj utvrđivanja programa politike suzbijanja zloporabe novih psihoaktivnih tvari pokazuje sve bitne značajke politike u kojoj je na djelu ograničena javna vidljivost (May, 1990) te u kojoj dominantno sudjeluju uže skupine eksperata, a ne šire skupine aktera (Baumgartner i Jones, 1991). Unatoč tome što se postupno javlja potreba pojačanih napora i usmjeravanja pažnje javnosti na ovaj fenomen, potrebno je uzeti u obzir činjenicu da u Hrvatskoj postoje brojni javno-politički problemi koji čekaju na rješavanje, te se čini da, unatoč poduzetim naporima stručno-administrativnih službi, problematika novih psihoaktivnih tvari još uvijek ne uspijeva privući dovoljnu pažnju za prelazak u sljedeću fazu javno-političkog ciklusa, fazu formulacije politike.

Naprijed navedeno potkrepljuje zaključak kako pojava novih psihoaktivnih tvari u Republici Hrvatskoj nije dovoljno prepoznata kao značajniji problem javnih politika. Daljnji razvoj ove važne javne politike ovisi o kapacitetima zajednice da ju prepozna kao društveni problem u koji je potrebno 
intervenirati. Osim toga, njezin daljnji razvoj mogao bi ovisiti i o događajima koji mogu snažno preusmjeriti pozornost (eng. focusing events) na pitanje sprječavanja zloporabe novih psihoaktivnih tvari. Birkland (2013) jasno ističe da postoje područja javnih politika u kojima fokusirajući događaji nisu praćeni prevelikom prisutnošću javnosti te da se različitim oblicima interne mobilizacije neki program ili politiku može staviti na dnevni red političkog odlučivanja.

Slična situacija prisutna je i u drugim članicama Europske unije koje pokušavaju različitim pravnim mehanizmima (npr. uvođenjem privremenih popisa novih psihoaktivnih tvari, dopunama postojećih zakona o drogama i slično) utjecati na prelazak ove javne politike u sljedeću fazu javno-političkog ciklusa (EMCDDA, 2016). Moguće da će na jasnije prepoznavanje ovog javno-političkog problema utjecati i inicijativa o novoj zakonodavnoj regulativi ovih tvari koju je u prosincu 2016. Vijeće Europske unije prepoznalo kao učinkovitiji odgovor na ovaj izazov (Council of the EU, 2016), a koja se sastoji od unaprjeđenja razmjene informacija, procjene rizika povezanih s novim psihoaktivnim tvarima te kreiranja učinkovitijih i bržih odgovora na ovaj problem.

Možda se mogućnost daljnjeg razvoja politike suzbijanja zlouporabe novih psihoaktivnih tvari na ovom mjestu može usporediti s politikom borbe protiv alkoholizma, koja je uspješno stavljena na dnevni red političkog odlučivanja Europske unije, početkom 2000-ih godina. O tome u svojoj knjizi u kojoj razmatraju proces stvaranja politika EU pišu nizozemski istraživači javnih politika Esther Versluis, Mendeltje van Keulen i Paul Stephenson (2010). Oni, naime, polaze od toga, da je za razumijevanje uspješnosti ciklusa postavljanja politike na dnevni red važno usporedno razumjeti djelovanje triju čimbenika, koji su prethodno i razmatrani u ovom članku. Prvi se odnosi na davanje okvira policy problemu (eng. issue framing), kojim se ističe način na koji je uopće definirano neko pitanje ili problem promatrane politike. Drugi čimbenik se odnosi na institucionalne strukture, mjesto (eng. policy venue) na kojem se odlučuje o toj politici, na što su u svojim radovima snažno upozorili Baumgartner i Jones (2009). I na kraju, bitan čimbenik je i vremenski kontekst, „prozor javnih politika", kratko razdoblje u kojem se na neko pitanje usredotočuje znatna pozornost i odluka o tom pitanju može biti donesena, o čemu smo govorili pozivajući se na doprinose Johna Kingdona.

Promatra li se politika borbe protiv alkoholizma najprije putem davanja okvira policy problemu, upozoravaju Versluis i suradnici (2010), može se lako uočiti da su od sredine 1990-ih pojedine vlade zemalja članica i nevladine organizacije pokušavale postaviti pitanje alkoholizma na dnevni red EU politika. No, na konzumiranje alkohola tada se gledalo samo kao na pitanje slobode protoka roba, kao temelja politike unutarnjeg tržišta (eng. EU single market policy). Ipak, nakon sve većeg isticanja zdravstvenih posljedica alkoholizma to pitanje je na postupan način postalo socijalnim pitanjem koje snažno utječe na javno zdravlje. Drugim riječima, pitanju alkoholizma pristupilo se novim okvirom kojim se isticala važnost javnog zdravlja, a ne nesmetanog funkcioniranja jedinstvenog europskog tržišta. To je donijelo dvije posljedice za dnevni red. Umjesto usmjeravanja na liberalizaciju tržišta, fokus se preusmjerio na restrikcije. Promijenila se, ujedno, i struktura onih koji sudjeluju u postavljanju dnevnog reda, budući da su umjesto aktera zainteresiranih isključivo za pitanja liberalizacije tržišta, u igru ušli akteri koje je prije svega zanimalo pitanje javnog zdravlja. Nakon toga valja razmotriti i ulogu drugog čimbenika, institucionalnih struktura. Riječ je o mjestu, institucionalnoj točki koja ima ovlasti donijeti odluku o nekom pitanju. Institucije, pri tome, nisu neutralne. Njihova prijemčivost za pojedine prijedloge politika bitno određuje i mogućnosti postavljanja programa. Zagovornici ograničavanja alkoholizma djelovali su na Opću upravu za zdravlje i 
zaštitu potrošača Europske komisije, a podržala ih je i Svjetska zdravstvena organizacija. Proizvođači alkohola obraćali su se, pak, Općoj upravi (DG) za Unutarnje tržište, industriju, poduzetništvo i malo i srednje poduzetništvo Europske komisije. Nakon što je promijenjen okvir razumijevanja pitanja alkohola s pitanja slobode prometa alkoholnih proizvoda na okvir koji je isticao pitanje alkoholizma kao javnog zla (eng. public bad) u istu liniju dolaze okvir i mjesto stvaranja politike. Ostalo je još da se s time poklopi djelovanje trećeg čimbenika - vremenskog okvira, odnosno, prozora javnih politika. Za njegovu pojavu ključni su fokusirajući događaji, kojima se pozornost kreatora javnih politika fokusira na neko pitanje. Pitanje alkoholizma nepunoljetnih osoba, kao važan socijalni problem, postalo je takvim događajem u trenutku kad je Švedska 2001. preuzela predsjedanje Europskom unijom. U tom trenutku su se poklopili okvir, mjesto odlučivanja o politici i vremenski okvir i politika je bila stavljena na formalni dnevni javnih politika.

Moguće je stoga da će daljnji razvoj politike sprječavanja zloporabe novih psihoaktivnih tvari biti potaknut procesima europeizacije i transferom politike s europske razine, dođe li do harmonizacije te politike na europskoj razini. Dok se to ne dogodi, ostaje samo strategija podizanja znanja javnosti o negativnlm učincima novih psihoaktivnih tvari na zdravlje nacije, s nastojanjem da to pitanje dobije veću pozornost hrvatske javnosti. S jačanjem pozornosti koju javnost iskazuje prema tom pitanju veće su i šanse da će se pojaviti akter (kojeg Kingdon (1984) naziva policy poduzetnikom) koji će to pitanje uspjeti staviti na formalni dnevni red javnih politika.

\section{Literatura}

Baumgartner, F.R., Jones, B.D. (1991): Agenda Dynamics and Policy Subsystems. Journal of Politics. 53 (4). 1044-1074.

Baumgartner, F.R., Jones, B.D. (2009): Agendas and Instability in American Politics, 2nd Ed. Chicago: The University of Chicago Press.

Baumgartner, F.R., Green-Pedersen, C., Jones, B. D. (2006): Comparative studies of policy agendas. Journal of European Public Policy. 13 (7). 959-974. doi:10.1080/13501760600923805

Birkland, T.A., DeYoung, S.E. (2013): Focusing events and policy window. U Araral, E., Fritzen, S., Howlett, M., Ramesh, M., Wu, X. (Ur.), Routledge Handbook of Public Policy. London: Routledge, 175-188.

Cairney, P. (2013): Understanding Public Policy: Theories and Issues. Basingstoke: Palgrave Macmillan.

Cobb, R., Ross, J.-K., Ross, M.H. (1976): Agenda Building as a Comparative Political Process. The American Political Science Review, 70 (1). 126-138.

Colebatch, H. K. (2004): Policy. Zagreb: Fakultet političkih znanosti.

Colebatch, H.K. (2005): Policy analysis, policy practice and political science. Australian Journal of Public Administration. 64 (3). 14-23. doi: 10.1111/j.1467-8500.2005.00448.x

Council of the European Union (1997): Joint Action concerning the information exchange, risk assessment and control of new synthetic drugs of 16 June 1997, OJ L 167, 25.06.1997.

Council of the European Union (2005): Council Decision 2005/387/JHA of 10 May 2005 on the Information Exchange, Risk-Assessment and Control of New Psychoactive Substances, OJ L 127, 20.05.2005. 
Council of the European Union (2016): Council adopts its position on the reform of the new psychoactive substances regislation. Press release 730/16, 08/12/2016. http://WwW. consilium.europa.eu/en/press/press-releases/2016/12/08-psychoactive-substances/ (Pristupljeno 17.1.2017.)

Dearing, J.W., Rogers, E.M. (1996): Agenda-Setting. Thousand Oaks: Sage.

Doležal, D. (2012): Prikaz rezultata projekta Distribucija i cijena ilegalnih droga u RH, U: Milković, M., Doležal, D., Hržica, G., Stošić, J. (Ur.), Istraživanja u edukacijsko-rehabilitacijskim znanostima. Izlaganje s 8. međunarodnog znanstvenog skupa Istraživanja u edukacijsko-rehabilitacijskim znanostima. Zagreb, 27.-29. rujna 2012. Zagreb: Sveučilište u Zagrebu, 83.

Downs, A. (1972): Up and Down with Ecology-the Issue-Attention Cycle. Public Interest. 28, 38-50.

European Commission (2014): Flash Eurobarometer. Young people and drugs. Report. Flash Eurobarometer 401 - TNS Political \& Social. http://ec.europa.eu/commfrontoffice/publicopinion/flash/fl_401_en.pdf (Pristupljeno 20.1.2017.)

European Monitoring Centre for Drugs and Drug Addiction (EMCDDA) (2007): Early-Warning System on New Psychoactive Substances. Operating Guidelines. Luxembourg: Office for Official Publications of the European Communities.

European Monitoring Centre for Drugs and Drug Addiction (EMCDDA) (2014): European Drug Report - Trends and Developments 2014. Luxembourg: Publications Office of the European Union. doi:10.2810/32890

European Monitoring Centre for Drugs and Drug Addiction (EMCDDA) (2016): European Drug Report: Trends and Developments. European Monitoring Centre for Drugs and Drug Addiction. Luxembourg: Publications Office of the European Union.

EMCDDA / Europol (2012): EMCDDA / Europol 2011 Annual Report on the Implementation of Council Decision 2005/387/JHA. Luxembourg: Publications Office of the European Union.

EMCDDA / Europol (2013): New Drugs in Europe, 2012. EMCDDA / Europol 2012 Annual Report on the Implementation of Council Decision 2005/387/JHA. Luxembourg: Publications Office of the European Union. doi:10.2810/99367

European Monitoring Centre for Drugs and Drug Addiction and Eurojust (2016): New psychoactive substances in Europe: Legislation and prosecution - current challenges and solutions. EMCDDA-Eurojust joint publication. Luxembourg: Publications Office of the European Union. doi:10.2810/777512

Glavak Tkalić, R., Miletić, G-M., Maričić, J. (2016): Uporaba sredstava ovisnosti u hrvatskom društvu: Istraživanje na općoj populaciji. Zagreb: Institut društvenih znanosti Ivo Pilar i Ured za suzbijanje zlouporabe droga Vlade Republike Hrvatske.

Grdešić, I. (1995): Političko odlučivanje. Zagreb: Alinea.

Green-Pedersen,C., Mortensen, P.B. (2013): Policy agenda-setting studies: Attention, politics and the public. U: Araral, E., Fritzen, S., Howlett, M., Ramesh, M., Wu, X. (Ur.), Routledge Handbook of Public Policy. London: Routledge, 167-174.

Hague, R., Harrop M., Breslin S. (2001): Komparativna vladavina i politika. Zagreb: Fakultet političkih znanosti.

Hajer, M. (2003): Policy without polity? Policy analysis and the institutional void. Policy Sciences, 36. 175-195. 
Dijana Jerković, Zdravko Petak : Utvrđivanje programa politike suzbijanja zlouporabe novih...

Hill, M. (2010): Proces stvaranja javnih politika. Zagreb: Fakultet političkih znanosti.

Hogwood, B., Gunn, L.A. (1984): Policy Analysis for the Real World. Oxford: Oxford University Press.

Howlett, M., Ramesh, M., Perl, A. (2009): Studying Public Policy - Policy Cycles \& Policy Subsystems. Third Edition. Toronto: Oxford University Press.

Huhges, B., Ewans-Brown, M. (2015): New psychoactive substances in Europe. Innovative legal responses. EMCDDA. Luxembourg: Publications Office of the European Union. doi:10.2810/90544

Jerković, D. (2015): Samoodređenost studenata u studenskim naseljima i učestalost konzumiranja alkohola i kanabinoida. Neobjavljeni doktorski rad. Edukacijsko-rehabilitacijski fakultet Sveučilišta u Zagrebu.

Jerković, D. (2016): Izazovi novih psihoaktivnih tvari. U D. Roviš (Ur.), Izazovi izgradnje cjelovitog pristupa prevenciji ovisnosti te liječenju, resocijalizaciji i socijalnoj reintegraciji ovisnika u Republici Hrvatskoj - Analiza stanja i potreba te iskustava Primorsko-goranske županije. Rijeka: Medicinski fakultet Sveučilišta u Rijeci i Nastavni zavod za javno zdravstvo Primorsko-goranske županije, 33-44.

John, P. (1998): Analysing Public Policy. London: Pinter.

Jones, B. D., Baumgartner, F.R. (2005): The Politics of Attention. How Government Prioritizes Problems. Chicago: The University of Chicago Press.

Jones, B. D., Baumgartner, F.R. (2012): From There to Here: Punctuated Equilibrium to the General Punctuation Thesis to a Government Information Processing. Policy Studies Journal. 40 (1). 1-19.

Kingdon, J. W. (1984): Agendas, Alternatives and Public Policies. Boston: Little, Brown \& Company.

Kovčo Vukadin, I. (2014): Ispitivanje kvalitete života studenata u Republici Hrvatskoj. Istraživačko izvješće. https://drogeiovisnosti.gov.hr/o-uredu/djelokrug/ovisnosti-i-vezane-teme/droge-i-ovisnost/publikacije/istrazivanja/istrazivanje-kvalitete-zivota-studenata-erf-2014/1071 (Pristupljeno 10.2.2017.)

Kranželić, V., Jerković, D. (2012): Istraživanja novih trendova u konzumiranju sredstava ovisnosti - iskustva i rezultati on-line pilot istraživanja, U: Milković, M., Doležal, D., Hržica, G., Stošić, J. (Ur.), Istraživanja u edukacijsko-rehabilitacijskim znanostima. Izlaganje s 8. međunarodnog znanstvenog skupa Istraživanja u edukacijsko-rehabilitacijskim znanostima, 27.-29. rujna 2012. Zagreb: Sveučilište u Zagrebu, 83-84.

Kranželić, V., Doležal, D. (2013): Online istraživanje pojavnosti novih droga u Republici Hrvatskoj. https://drogeiovisnosti.gov.hr/UserDocs/mages/uredarhiva/2013/11/2013_novi_trendovi. pdf (Pristupljeno 14.2.2017.)

Kraus, L., Guttormsson, U., Leifman, H., Arpa, S., Molinaro, S., Monshouwer, K. et al. (2016): ESPAD Report 2015: Results from the European School Survey Project on Alcohol and Other Drugs. European Monitoring Centre for Drugs and Drug Addiction \& The European School Survey Project on Alcohol and Other Drugs. Luxembourg: Publications Office of the European Union.

Kustec Lipicer, S. (2012): Vrednovanje javnih politika. Zagreb: Disput.

May, P.J. (1990): Reconsidering Policy Design: Policies and Publics. Journal of Public Policy 11 (2). 187-206. 
Mazmanian, D. A., Sabatier, P. A. (1980): A Multivariate Model of Public Policy-Making.

Nacionalna strategija suzbijanja zlouporabe (opojnih) droga u Republici Hrvatskoj za razdoblje 2006.-2012, Narodne novine 147/2005.

Nacionalna strategija suzbijanja zlouporabe droga u Republici Hrvatskoj za razdoblje 2012.-2017, Narodne novine 122/2012.

Petak, Z. (2007): Javne politike: razvoj discipline u Hrvatskoj i svijetu. U: Kasapović, M. (Ur.), Izlazak iz množine? Stanje hrvatske političke znanosti. Zagreb: Fakultet političkih znanosti, 187-215.

Petak, Z. (2008): Dimenzije javnih politika i javno upravljanje. Politička misao. 45 (2). 9-26.

Petek, A. (2012): Transformacija politike prema osobama s invaliditetom: primjena policy mreža. Doktorski rad. Zagreb: Fakultet političkih znanosti. https://bib. irb.hr/datoteka/568532. Doktorat_AP__final.pdf (Pristupljeno 10.2.2017.)

Petek, A. (2014): Dnevni red. U: Petek, A., Petković, K. (Ur.), Pojmovnik javnih politika. Zagreb: Fakultet političkih znanosti, 54-55.

Popis droga, psihotropnih tvari i biljaka iz kojih se može dobiti droga te tvari koje se mogu uporabiti za izradu droga. Narodne novine, 10/2016.

Princen, S. (2009): Agenda-Setting in the European Union. Basingstoke: Palgrave Macmillan.

Protokol o Sustavu ranog upozoravanja u slučaju pojave novih psihoaktivnih tvari u Republici Hrvatskoj. Vlada Republike Hrvatske, 02. studenog 2007.

Sabatier, P.A., Jenkins-Smith, H.C. (1993): Policy Change and Learning: An Advocacy Coalition Framework. Boulder: Westview Press.

Schneider, A., Ingram, H. (1993): Social Construction of Target populations: Implications and Policy. American Political Science Review 87 (2). 334-347.

Sharp, E.B. (1992): Agenda-Setting and Policy Results: Lessons From Three Drug Policy Episodes. Policy Studies Journal 20 (4). 538-551.

Stone, D. (2012): Policy Paradox: The Art of Political Decision-Making. New York: W.W. Norton \& Company.

United Nations Office on Drugs and Crime (UNODC) (2015): World Drug Report. New York: United Nations.

Uredba o osnivanju Ureda za suzbijanje zlouporabe opojnih droga, Narodne novine 18/2002, $12 / 2005,111 / 2006,19 / 2010,36 / 2012,130 / 2012$.

Ustav Republike Hrvatske, Narodne novine 56/1990, 135/1997, 113/2000, 28/2001, 76/2010, 5/2014.

Versluis, E., van Keulen, M., Stephenson, P. (2010): Analyzing the European Union Policy Process. Basingstoke: Palgrave Macmillan.

Young, D., Borland, R., Coghill, K. (2010): An Actor-Network Theory Analysis of Polcy Innovation for Smoke-Free Places: Understanding Change in Complex Systems. American Journal of Public Health. 100 (7). 1208-1217.

Young, E., Quinn, L. (2007): Pisanje djelotvornih prijedloga za javne politike: vodič za policy savjetnike u zemljama Srednje i Istočne Europe. Zagreb: DIM. 
Dijana Jerković, Zdravko Petak : Utvrđivanje programa politike suzbijanja zlouporabe novih...

Zakon o potvrđivanju Sporazuma između Republike Hrvatske i Europske unije o sudjelovanju Republike Hrvatske u radu Europskog centru za praćenje droga i ovisnosti o drogama, Narodne novine, 03/2013, Međunarodni ugovori.

Zakon o suzbijanju zlouporabe (opojnih) droga, Narodne novine, br. 107/2001, 87/2002, 163/2003, 141/2004, 40/2007, 149/2009, 84/2011.

http://nijd.uredzadroge.hr/medunarodna-suradnja/europski-centar-za-pracenje-droga-i-ovisnosti-o-drogama-emcdda/ (Pristupljeno 05/12/2016). 